\title{
Statyba
}

\section{MULTIPLE CRITERIA EVALUATION OF CONSTRUCTION TENDERS IN ACCORDANCE WITH THE LAW ON PUBLIC PROCUREMENT OF THE REPUBLIC OF LITHUANIA}

\section{S. Mitkus \& T. Dejjus}

To cite this article: S. Mitkus \& T. Dejus (2000) MULTIPLE CRITERIA EVALUATION OF CONSTRUCTION TENDERS IN ACCORDANCE WITH THE LAW ON PUBLIC PROCUREMENT OF THE REPUBLIC OF LITHUANIA, Statyba, 6:6, 440-444, DOI: 10.1080/13921525.2000.10531628

To link to this article: https://doi.org/10.1080/13921525.2000.10531628

曲 Published online: 26 Jul 2012.

Submit your article to this journal $₫$

山ll Article views: 167

Citing articles: 2 View citing articles 5 


\title{
MULTIPLE CRITERIA EVALUATION OF CONSTRUCTION TENDERS IN ACCORDANCE WITH THE LAW ON PUBLIC PROCUREMENT OF THE REPUBLIC OF LITHUANIA
}

\author{
S. Mitkus, T. Dejjus
}

Vilnius Gediminas Technical Universit!

\section{Introduction}

In order to select an optimal construction (repairs) tender one should evaluate at least several criteria. The problems of the multiple criteria evaluation of tenders have been examined in literature rather widely $[1,2$, 3]. Yet, when organizers of biddings for construction contracts intend to procure construction contracts for funds from the government budget, local self-administration budgets and similar funds such organizers should act in accordance with the Law on Public Procurement of the Republic of Lithuania (hereinafter referred to as the LPP) [4].

The new edition of the PPL came into force on October 1, 1999. Although the concept of the multiple criteria evaluation is used neither in this law nor in the normative by-laws this law provides for the possibility to choose the criterion of the economically efficient tender as a criterion of evaluation of tenders. Item 4 of Article 26 of the LPP has charged the Government of the Republic of Lithuania with the task of approving the methods of determining the evaluation criterion of the economically efficient tender. On December 30. 1999 Government of the Republic of Lithuania approved these methods by Resolution No 1503 [5]. The analysis of the methods approved by this Resolution allow:s to maintain that these methods will secure the possibility of the multiple criteria evaluation.

This paper is aimed at analysing the possibility of using the multiple criteria ev aluation of construction tenders by taking into account the scientific achievements and principles of the LPP.

\section{Algorithm of evaluation of construction tenders}

When a bidding for construction contract is organized in accordance with the LPP, the algorithm of evaluation of tenders shall be strictly regulated. The procuring organization should provide for all the requirements concerning contractors and their tenders in the procurement documents. In the course of evaluation of received tenders, one should first of all evaluate the formal requirements for tenders that are stipulated by the procurement documents and LPP. Let us assume that the customer has received multitude $\boldsymbol{n}$ of tenders:

$$
B=\left\{B_{1}, B_{2}, \ldots, B_{n}\right\}, n \geq 3 .
$$

If the number of received tenders is less than two, the bidding shall be regarded as not taken place.

Matrix A (Table 1) of satisfying formal requirements for the tenders received may be formed upon receipt of tenders from contractors.

Table 1. Matrix A of satisfying formal requirements for tenders

\begin{tabular}{|c|c|c|c|c|}
\hline $\boldsymbol{B}_{i} \boldsymbol{F}_{j}$ & $\boldsymbol{F}_{1}$ & $\boldsymbol{F}_{2}$ & $\ldots$ & $\boldsymbol{F}_{m}$ \\
\hline $\boldsymbol{B}_{1}$ & $a_{11}$ & $a_{12}$ & $\ldots$ & $a_{1 m}$ \\
\hline $\boldsymbol{B}_{2}$ & $a_{21}$ & $a_{22}$ & $\ldots$ & $a_{2 m}$ \\
\hline$\ldots$ & $\ldots$ & $\ldots$ & $\ldots$ & $\ldots$ \\
\hline $\boldsymbol{B}_{n}$ & $a_{n 1}$ & $a_{n 2}$ & $\ldots$ & $a_{n m}$ \\
\hline
\end{tabular}

where $F_{j}$ - formal requirements for tenders. Some formal requirements are stipulated in the PPL (tenders should be bound. signed. sealed. et(). other requirements are determined by the procuring organization itself (mandatory information. requirements for work. etc).

Elements $~$, of the matrix of received tenders are binary. they indicate whether tender $B$, satisfies requirement $F_{j}$. ie their values may be set to YES or NOT.

The LPP provides for an imperative principle under which the tenders not satisfying the requirements as provided by the law and procurement documents shall be rejected, ie tender $B_{i}$ shall be rejected if the following condition is satisfied: 


$$
a_{i j}=\text { "NO" where at least one } j=\overline{\mathrm{l}, m}
$$

Upon rejection of the tenders that do not satisfy the formal requirements we shall obtain the multitude of tenders that satisfy the formal requirements:

$$
C=\left\{C_{1}, C_{2}, \ldots, C_{k}\right\}, 3 \leq k \leq n .
$$

The imperative norm of the LLP (Part 1 of Article 7) requires that the procuring organization should find out whether the contractor is competent, reliable and able to fulfil the conditions of the procured construction contract. Therefore. at a certain stage of the procuring procedure the procuring organization shall be entitled to require that the contractor should submit documents confirming qualification of the latter.

In order to evaluate qualification of contractors one should make up matrix D (Table 2) for evaluation of contractors' qualification.

Table 2. Matrix D for evaluation of contractors' qualification

\begin{tabular}{|c|c|c|c|c|}
\hline$B_{i} n_{j}$ & $K_{1}$ & $K_{2}$ & $\ldots$ & $K_{l}$ \\
\hline$B_{1}$ & $d_{11}$ & $d_{12}$ & $\ldots$ & $d_{1 l}$ \\
\hline$B_{2}$ & $d_{21}$ & & $\ldots$ & $d_{2 l}$ \\
\hline$\ldots$ & $\ldots$ & $d_{22}$ & $\ldots$ & $\ldots$ \\
\hline$B_{k}$ & $d_{k 1}$ & $d_{k 2}$ & $\ldots$ & $d_{k l}$ \\
\hline
\end{tabular}

where $K_{j}$ - qualification requirements for contractors as provided for in the procurement documents. Elements $d_{i j}$ of the contractors' qualification matrix are binary, they show whether qualification of the contractor who submitted tender $B_{i}$ satisfies qualification requirement $K_{j}$ provided for in the qualification documents. ie their values may be set to YES or NO. An imperative principle is stipulated in the LLP which maintains that the tenders submitted by all contractors shall be rejected if they do not meet the requirements specitied in the bidding documents. ie a tender shall be rejected. if the following condition is satislied:

$$
d_{\prime \prime}=\cdots \text { NO" where at least one } i=\overline{I . l} \text {. }
$$

A procuring organization may also reject tenders submitted by contractors in the following cases:

1) the contractor who submitted a tender has infringed upon the Competition Law;

2) all contractors have offered prices that are too high and not acceptable for the procuring orga- nization. Tenders may be rejected on these grounds only upon obtaining a permit issued by the Public Procurement Agency:

3) the offered prices are too low and the contractor has failed to substantiate them. The procuring organization may reject a tender on these grounds only in case where the contractor fails to substantiate it upon receiving a request to substantiate the price in writing.

Upon rejection of tenders that fail to meet the requirements, we obtain multitude $E$ of tenders to be evaluated:

$$
E=\left\{E_{1}, E_{2}, \ldots, E_{p}\right\}, p \leq l .
$$

If there are three or more tenders remaining. the received tenders shall be evaluated in accordance with the procedure as provided for in the bidding documents. If there are three or less tenders remaining after rejection of a tender, the bidding is regarded as one that has not taken place, whilst the procurement organization may choose to adopt the following resolutions:

1) to organize negotiated tenders if there are two tenders remaining to be evaluated upon rejection of tenders;

2) to effect a single-source procurement if upon rejection of tenders there is only one tender remaining to be evaluated. If the value of work is in excess of 500 thousand Litas, realization of such a procurement will require consent from the Public Procurement Agency;

3) to announce a new bidding. In this case all tenders shall be rejected, which also requires consent from the Public Procurement Department.

\section{Multiple criteria evaluation of tenders}

The LPP provides for the possibility of using the criterion of the economically efficient tender during evaluation of tenders. This criterion may be used in the case of procuring a construction contract by open tenders. limited tenders and negotiated tenders if the procuring organization has prosided for such kind of tenders in the procurement documentation.

The L.PP provides for strict limitations in cases where the procuring organization may evaluate tenders using the evaluation criterion of the economically efficient tender, ie when one may use multiple criteria evaluation of tenders. Economic usefulness of construction tenders may be evaluated only if both of these conditions are present: 
1) the construction work is being procured in combination with the project services of the procured object of work. In case when the work is procured under the preliminarily prepared project covering the constructional and technical solutions. economic efficiency cannot be evaluated:

2) determination of limits of technical parameters (functional parameters and operating costs) of the procured object in the procurement documentation does not guarantee the procuring organization a sufficiently good selection of tenders.

In addition to the price, the evaluation of economic efficiency may include evaluations of functional properties and operating costs or one of them. Operating costs may be evaluated in the following cases where there is an opinion that:

1) operating costs of the construction object will amount to not less than $50 \%$ of the object's construction price within the usual period of operation, yet, no longer than 10 years:

2) the permissible difference of operating costs in different tenders may exceed $15 \%$.

Functional properties can be evaluated only if both of the following conditions are present:

1) improvement of functional parameters of the erected object is important for the needs of the procuring organization;

2) difference of essential functional parameters in different tenders may exceed $15 \%$.

Analysis of the procedure of determining the economically efficient tender [5] approved by resolution of the Government allows to draw a conclusion that these methods provide the multiple criteria evaluation of tenders in accordance with the MWSDI criterion [2].

When evaluating tenders in accordance with the criterion of the economically efficient tender. the procuring organization may evaluate the tender's price. functional properties of the procurement object and operating costs of this object. Matrix $U$ of decision-making in accordance with the above procedure is shown in Table 3 .

Functional parameters may include technical characteristics of the procurement object thermal resistance. stability. durability). aesthetic properties. impact upon the environment. etc. Operating costs are future costs associated with the utilization of the erected object. Only those costs may be added which are selected for evaluation of tenders and specified in the procurement documents. Index duplication should be avoided while determining the functional properties and operating costs
Table 3. Decision-making matrix $U$

\begin{tabular}{|c|c|c|c|c|c|c|}
\hline $\begin{array}{c}\text { Tenders } \\
\text { under } \\
\text { evaluation }\end{array}$ & \multirow{2}{*}{ Price } & \multicolumn{4}{|c|}{ Functional parameters } & \multirow{2}{*}{$\begin{array}{c}\text { Operating } \\
\text { costs }\end{array}$} \\
\cline { 2 - 7 } & $F_{1}$ & $F_{2}$ & $\ldots$ & $F_{r}$ & \\
\hline$E_{1}$ & $c_{1}$ & $f_{11}$ & $f_{12}$ & $\ldots$ & $f_{1 r}$ & $e_{1}$ \\
\hline$E_{2}$ & $c_{2}$ & $f_{21}$ & $f_{22}$ & $\ldots$ & $f_{2 r}$ & $e_{2}$ \\
\hline$\ldots$ & $\ldots$ & $\ldots$ & $\ldots$ & $\ldots$ & $\ldots$ & $\ldots$ \\
\hline$E_{p}$ & $c_{p}$ & $f_{p 1}$ & $f_{p 2}$ & $\ldots$ & $f_{p r}$ & $e_{p}$ \\
\hline
\end{tabular}

to be evaluated. For instance, if the thermal resistance of the enclosure is chosen as a functional parameter, then the heating of the building should not be evaluated as operating costs, and vice versa, because there is a great inter dependence of these parameters.

The methods of normalizing the decision-making matrix, which methods are stipulated in the law and by-laws [4, 5], differ from the methods described in many scientific papers $[1,2,3]$. The greatest peculiarity lies in the fact that a two-level system of coefficients of importance is used (Table 4).

Table 4. System of coefficients of importance

\begin{tabular}{|c|c|c|c|c|c|c|}
\hline Levels & $\begin{array}{c}\text { Coefficient of } \\
\text { importance } \\
\text { of price }\end{array}$ & \multicolumn{4}{|c|}{$\begin{array}{c}\text { Coefficients of } \\
\text { importance of } \\
\text { functional parameters }\end{array}$} & $\begin{array}{c}\text { Coefficient of } \\
\text { importance of } \\
\text { operating costs }\end{array}$ \\
\cline { 3 - 6 } & & 1 & 2 & $\ldots$ & $R$ & \\
\hline 1 & $X$ & \multicolumn{4}{|c|}{$Y_{f}$} & $Y_{e}$ \\
\hline 2 & & $L_{1}$ & $L_{2}$ & $\ldots$ & $L_{r}$ & \\
\hline
\end{tabular}

The procuring organization shall specify the coefficients of importance of the price, functional parameters and operating costs in the procurement documents. which coefficients shall total up to 100 :

$$
x+y_{1}+y_{c}=100 \text {. }
$$

where $.1 .1, .1$. - coefficients of importance of the price. functional parameters and operating costs. respectively.

Four methods of determining coefticients of imponance are widely analysed in the literature: ie methods of entropy. index value loss. expert test and the complex method [1, 2, 3]. The peculiarity of all these methods, with exception of the expert test method, lies in the fact that they are determined upon formation of the alternatives to be evaluated and upon determination of coefficient values of these alternatives, which values 
are to be evaluated. The LPP expressively requires that the coefficients of importance to be evaluated should be already specified in the bidding documents, ie prior to formation of the tender matrix. This requirement does not allow to use many possibilities of the multiple criteria evaluation so that the procuring organizations have to resort to the sole opportunity of determining the coefficients of importance, ie by the expert test method. Procurement is often carried out by commissions created by procuring organizations themselves whereof members are not initiated into the multiple criteria evaluation methods. Therefore, having failed to determine the correct coefficients of importance, they may choose to proclaim the tender, which is not the most suitable, the winner, which fact may be considered a drawback in case of applying this method to public procurement.

By-laws provide further restrictions with regard to coefficients of importance. In case of procuring construction work contracts, the coefficient of importance of price evaluation cannot be less than 70 , when the price, functional properties and operating costs are evaluated, and cannot be less than 80 , when only functional properties or operating costs are evaluated besides the price.

As we can see, irrespective of the fact that there may be several functional properties to be evaluated, only one coefficient of importance shall be assigned to the multitude of them. Therefore, coefficients of importance $L_{i}$ of the second level whereof total sum equals to one shall be assigned to each functional parameter.

Taking into account the above-mentioned peculiarities the decision-making matrix shall be normalized in the following way. First of all, normalized values of generalized functional parameters shall be calculated by evaluating their coefficients of importance $L_{i}$ :

$$
f_{i}^{\prime \prime}=\Sigma F_{i}
$$

where $F_{i}$ - evaluation of the $i$-th functional parameter. which is calculated in accordance with one of these formulas:

$$
\begin{aligned}
& F_{1}=\left(P_{1}, P_{\text {mid }}\right) \cdot L_{1} . \\
& F_{1}=\left(r_{\text {min }} P_{1}\right) \cdot l_{1} .
\end{aligned}
$$

Where $P_{1}$ - value of the $i$-th functional parameter: $P_{\text {nun }}$. $P_{\text {mas }}$ - respectively. the minimum or maximum value of the $i$-th parameter offered by the contractors. Formula $(8)$ is used when the best values of technical parameters are set to maximum, and formula $(9)$ is used when the best values of technical parameters are set to minimum.
The offered prices shall be normalized in accordance with the following formula:

$$
c_{i}^{\prime \prime}=c_{\min } / c_{i}
$$

where $c_{\min }$ and $c_{i}$ - the offered minimum price and the one of the currently considered tender, respectively.

The offered operating costs shall be normalized in accordance with the following formula:

$$
e_{i}^{\prime \prime}=e_{\min } / e_{i},
$$

where $e_{\min }$ and $e_{i}$ - the offered minimum operating costs and the ones of the currently considered tender. respectively.

Normalized decision-making matrix $N$ (Table 5) obtained upon normalization.

Table 5. Normalized decision-making matrix $\mathrm{N}$

\begin{tabular}{|c|c|c|c|}
\hline $\begin{array}{c}\text { Tenders } \\
\text { under } \\
\text { evaluation }\end{array}$ & $\begin{array}{c}\text { Normalized } \\
\text { value of } \\
\text { price }\end{array}$ & $\begin{array}{c}\text { Normalized } \\
\text { value of } \\
\text { technical } \\
\text { parameters }\end{array}$ & $\begin{array}{c}\text { Normalized } \\
\text { value of } \\
\text { operating } \\
\text { costs }\end{array}$ \\
\hline$B_{1}$ & $c_{1}^{\prime \prime}$ & $f_{1}^{\prime \prime}$ & $e_{1}^{\prime \prime}$ \\
\hline$B_{2}$ & $c_{2}^{\prime \prime}$ & $f_{2}^{\prime \prime}$ & $e_{2}^{\prime \prime}$ \\
\hline$\ldots$ & $\ldots$ & $\ldots$ & $\ldots$ \\
\hline$B_{p}$ & $c_{p}^{\prime \prime}$ & $f_{p}^{\prime \prime}$ & $e_{p}^{\prime \prime}$ \\
\hline
\end{tabular}

Upon formation of the normalized decision-making matrix, the economic efficiency of each tender may be calculated in accordance with the formula:

$$
S_{i}=c_{i}^{n} \cdot X+f_{i}^{n} \cdot Y_{f}+e_{i}^{n} \cdot Y_{e} .
$$

A priority queue shall be established in accordance with the obtained values of economic efficiency. The procuring organization should propose the contractor who submitted the economically efficient tender to enter into the contract.

\section{Conclusions}

1. The Public Procurement Lan of the Republic of L.ithuania and by-laws stipulate that public procurement procedures shall be applied in eases where consiruction contracts are procured for the money of public and related funds. The above-mentioned lau provides a possibility to choose contractors by taking into account not only the minimum price offered but also in accordance with the criterion of the economically efficient tender. Analysis of the methods of determining 
the economically efficient tender approved by the resolution of the Government shows that by now the possibility to choose a contractor by application of the multiple criteria evaluation methods has been legally authorised.

2. Although the possibilities for applying multiple criteria evaluation to construction in general and to selection of the best tender submitted by contractors have been widely studied, yet, the application of multiple criteria evaluation by taking into account the currently effective legal norms. which regulate public procurement procedures, has not been investigated.

3. Analysis of legal norms regulating public procurement procedures shows that the multiple criteria evaluation has been legally approved only in accordance with one modified criterion known in the literature [2] under the name of MWSDI.

4. Research into the possibilities of applying methods of multiple criteria evaluation of construction tenders by taking into account the legal regulation of public procurement procedures would allow the procurement organizations to prepare procurement documentation of better quality, the contractors - to bid for construction contracts with more success, as well as to improve the legal normative base regulating the public procurement procedures.

\section{References}

1. A. Kaklauskas. Pastato gyvavimo proceso daugiakriteriniu sprendimu sistema. Habilitacinio darbo santrauka. Vilnius: Technika, 1999. 96 p.

2. E. K. Zavadskas, F. Peldschus, A. Kaklauskas. Multiple criteria evaluation of projects in construction / Institute of Technological and Economic Development (ITED). Vilnius Technical University. Vilnius: Technika. 1994. $226 \mathrm{p}$.

3. E. K. Zavadskas. A. Kaklauskas. E. Bejder. T. Motekūnas. Pastato starybos ir eksploatacijos daugiatikslè sclektonovacija. Vilnius: Technika. 1992. $82 \mathrm{p}$

4. Lictuvos Respublikos Viešuju pirkimy istatymas Valstybés tzinios. 1999. Nr. 56 1809.

5. Lietuvos Respublikos livriausytis 1999) m. gruodzio $30 \mathrm{~d}$ nutarimas Nr. 1503. . Dil ckonomiskai naudingiausio pasiülymo vertinimo kriterị! nustalymo meloxdikon patsirtinimo" lalstubis tinion. 2(KM). Nr. I 8.

licikta 2000) 1206
STATYBOS RANGOS PASIULYMU DAUGIATIKSLIS VERTINIMAS, ATSIŽVELGIANT I LIETUVOS RESPUBLIKOS VIEŠUJU PIRKIMU ISTATYMO NUOSTATAS

\section{S. Mitkus, T. Dèjus}

\section{Santrauka}

Norint tinkamai ivertinti statybos rangos pasiūlymus, būtina ivertinti bent keleta kriteriju. Nors statybos rangos pasiūlymu daugiatikslis vertinimas yra pakankamai plačiai išnagrinètas literatūroje. toks vertinimas, atsižvelgiant i Lietuvos Respublikos viešuju pirkimu istatymą iki šiol moksliškai nenagrinètas.

Nors nei šiame istatyme. nei poistatyminiuose norminiuose aktuose nevartojama daugiatikslio ivertinimo sąvoka. šiuo istatymu yra îvirtinta galimybé pasiūlymų vertinimo kriterijumi pasirinkti ekonomiškai naudingiausio pasiūlymo kriteriju. Straipsnyje atlikta teisès aktu analizè rodo. kad vertinant rangovu pasiūlymus pagal ekonomiškai naudingiausio pasiūlymo vertinimo kriteriju yra numatyta daugiatikslio rangovu pasiūlymu vertinimo galimybè.

Atlikta Viešuju pirkimu istatymo ir poistatyminiu teisès aktụ analizé rodo, kad rangovų pasiūlymụ daugiatikslị vertinimą galima suskirstyti $\mathfrak{i}$ tris stadijas.

Pirmojoje stadijoje yra atmetami pasiūlymai, kurie neatitinka konkurso dokumentu reikalavimu. Antrojoje stadijoje atmetami pasiūlymai $\mathfrak{\text { น }}$ tiekèju, kurie neatitinka perkančiosios organizacijos keliamy kvalifikaciniu reikalavimu.

Trečiojoje stadijoje atliekamas tinkamu pasiūlymų daugiatikslis vertinimas. Parodoma, kad vertinant rangovı pasiūlymus viešuosiuose pirkimuose gali būti taikomas modifikuotas daugiatikslio vertinimo kriterijus, kuris literatūroje yra žinomas MWSD1 vardu [2]. Pagrindinis jo skirtumas nuo literatūroje aprašyto yra dvieju lygiu svorio koeficienty sistema (4 lentelè). Viešuju pirkimu jstatymas ir poistatyminiai teisès aktai numato ir daugiau daugiatikslio vertinimo galimybiu apribojimu, kurie ir yra analizuojami straipsnyje.

Tolesnis statybos rangos pasiūlymu daugiatikslis vertinimas, atsižvelgiant $\mathfrak{i}$ Viešuju pirkimu istatymą, leistu užsakovams pasirinkti geresnius pasiūlymus. o rangovams - parengti konkurencingesnius.

Sigitas MITKUS. Doctor. Associate Professor. Dept of Constnuction Technology and Management. Vilnius Gediuninas Technical University. Saulètckio al. II. LT-2(10) Vilnius. Lithuania.

PhD (199) ). Rescarch interests: theon of multiple criteria decision)-making. marketing. construction law. Author or col-author of more than 211 papers.

Tilas DE்.JCS. Dector. Associalc Professor. Dept of Construction Technology and Management. Vilnius Ciediminas Technical University. Sauletckio al. II. LT-2040 Vïlnius. Lithuania.

PhD (1991). Research interests: theory of multiple criteria decision-making in practice, occupational safery at building sites, improvement of study process. Author or co-author of more than 25 papers. 